\title{
Editorial: 2021, a new decade starts
}

\author{
Jaime ALMANSA-SĀNCHEZ \\ Institute of Heritage Sciences (Incipit, CSIC) \\ jaime.almansa-sanchez@incipit.csic.es
}

We have just celebrated ten years of open access public archaeology, and now we carry on with our venture. Volume 11 brings with it a new layout and format, as well as a new timing for publication. Since our inclusion in Scopus, improving quality goes in hand with the improvement of publication time. This is why, from now on (although this year is still a transitional period), volumes will open in January and close in October, with articles being published when they are ready. We are also starting a new section for shorter articles, aimed at the reporting of projects or ideas with a more formal format than our section Points of You, which will continue to retain its op-ed style. Of course, the philosophy does not change. We want to continue to be an opportunity of wider accessibility for authors and readers, and to continue exploring the physical and thematic frontiers of the discipline.

Unlike in previous Editorials, we will no longer explain what is forthcoming, as, under the new system, we probably will not know this at the time the Editorial is written. Instead, this will simply provide an opportunity to address some timely topics and invite you to continue following and supporting us, as you have been doing all these years.

At the time of writing these lines, some distressing news is emanating from the UK. Chester, Leicester, and now Sheffield, seem to be considering a restructuring that will make their archaeology departments (and staff) redundant. We can appeal to feelings, and the impact this will have on friends and colleagues at those departments, but the impact goes further, and we cannot stand by and allow this continuous attack upon the social sciences in general, and the heritage sector in particular. And, with a stance identical to that of many colleagues worldwide, we can only hope that administrators reconsider these nonsensical plans, and allow the good research and teaching undertaken at these institutions to continue.

\section{AP: Online Journal in Public Archaeology - Volume 11 - ISSN: 2171-6315 \\ Almansa-Sánchez, J. 2021. Editorial: 2021, a new decade starts. AP: Online Journal in Public Archaeology 11, e1-e2.}

DOI: $10.23914 /$ ap.v11i0.323 


\section{e2 :: AP Journal v.11 :: EDITORIAL}

Being a public archaeology journal, we cannot stay silent about the latest events in the Levant. When the disaster of Daesh seemed to have been abated, violence between Israel and Palestine reappeared on the horizon. Staying silent is not an option, and we strongly condemn the relentless violence of the Israeli state against the Palestinian population, currently with bombs, but tomorrow once again with the usual structural violence witnessed over the last decades. We understand that the conflict is incredibly complex, and we also sympathise with the many Israeli citizens affected by it, especially those that continue to strive for peaceful relations and coexistence. In 2004 we suffered the pressure of the system in a forum exploring peace-making in which the main piece was withdrawn days before publication (see Volume 4: 31-50). Last year, Rafi Greenberg (Volume 10: 91-100) collaborated in the Futures' Forum addressing the use of public archaeology in 'digwashing' and the emancipatory possibilities of a public contemporary archaeology. Archaeology can be one of the tools used to ameliorate the conflict, but right now it is also being used in the wrong direction. Let's reconsider what we are doing and work for a better world.

We would like to finish with better news, but very recently we heard of the death of a very dear friend, Don Henson. As devastating as such news always is, we want to celebrate his life, his energy and his legacy within archaeology and education. He wrote a review of the Birmingham TAG back in our second volume, but unfortunately we will never get to receive a paper about his later work on the presentation of the Mesolithic (which Jaime persistently asked for at every conference they both attended). But his memory will always remain with us, and he will be a truly missed presence at in-person conferences, once they resume again. Rest in peace Don, this volume is dedicated to you.

Finally, it is also time for a farewell and a huge THANK YOU to our co-editor Elena Papagiannopoulou. She has been an essential part of this journal since the very beginning, and her attention to detail has been fundamental in getting us to where we are today. Finding balance between life and work is always difficult, and we must choose life first. But she will always be a part of this family.

For this volume, we welcome our colleague Andrew Lawler as copyeditor and see the promotion of Alejandra Galmés to reviews editor. Soon we will open a call for new roles to continue improving content, both in terms of numbers and quality. Meanwhile, please remember that, although costs are still covered by JAS Arqueología, we are a non-profit venture, and all help is always welcome. You can contribute directly via the 'Donations' button on the website, or by acquiring printed volumes of the journal. But the best form of contribution is the submission of quality content, so send us your manuscripts and become a part of the family, too! 